ISSN 1412 - 8837

\title{
ANALISIS PASOKAN TBS DAN HARGA CPO (STUDI KASUS KABUPATEN BENGKULU UTARA DAN PT. AGRICINAL)
}

\author{
Nusril 1) \\ Nyayu Neti Arianti1) \\ Rismaini2), \\ 1 Staff Pengajar Jurusan Sosial Ekonomi Pertanian Fak.Pertanian UNIB \\ 2 Alumni Jurusan Sosial Ekonomi Pertanian Fak.Pertanian UNIB
}

\begin{abstract}
North Bengkulu Sub-Province is one of the center area palm production in Bengkulu Province. PT. Agricinal is one of the national private big plantation in North Bengkulu Sub-Province, meed needs raw material become from central plantation company and from society plantation. This Research aim to know how many FFB inclusion from society plantation North Bengkulu Sub-Province in PT. Agricinal (1), knowing result of forecast the FFB availibility in society plantation North Bengkulu Sub-Province (2) and CPO price in PT. Agricinal during 16 month future in start in 2005 September until 2006 December (3), and knowing CPO cost of goods manufactured in PT Agricinal in last period 2005 August (4). This research was carried out on 2005 September in North Bengkulu Sub-Province. The analysis data Method was adapted with that aim is descriptive analysis, exponential smoothing method and process cost of goods manufactured method. Based on result of research was knowing average FFB inclusion in PT. Agricinal from society plantation in North Bengkulu Sub-Province equal to $6.734,69$ ton or $50,60 \%$ (1). Result of forecast was availibilited FFB in society plantation North Bengkulu Sub-Province for 16 period in the future had been tended increasing (2). Result of forecast of CPO price in PT. Agricinal for 16 period in the future had been tended increasing (3). And result calculation of basic CPO cost of goods manufactured in PT. Agricinal in the last period 2005 August, known that CPO cost of finish good is equal to Rp 11.637.231.132,35 and CPO cost of work in proses is equal to Rp 4.562.873,65 (4).
\end{abstract}

Key Word : FFB Inclusion and CPO Price

\section{PENDAHULUAN}

Perkebunan kelapa sawit (Elaeis guineensis jacg) telah muncul menjadi andalan bagi penghasil pendapatan daerah. Kelapa sawit menghasilkan tandan buah segar (TBS) yang dapat diolah menjadi minyak sawit atau Crude Palm Oil (CPO) yang mempunyai manfaat sebagai bahan baku minyak goreng, margarin, sabun dan produk kosmetik. Kelapa sawit merupakan salah satu tanaman perkebunan yang mempunyai potensi sebagai salah satu penghasil bahan ekspor non migas. Saat ini Indonesia tercatat sebagai salah satu negara produsen kelapa sawit terbesar di dunia setelah Malaysia (Rachman dan Subroto, 1999) 
Pada awalnya, di Indonesia perkebunan kelapa sawit dilaksanakan oleh perkebunan besar negara dan perkebunan besar swasta. Masyarakat disekitar perkebunan hanya terlibat sebagai buruh dalam proses produksi dan pengolahan. Menyadari akan pentingnya peranan kelapa sawit, pemerintah telah merintis model pengembangan pembangunan perkebunan rakyat. Agar perkebunan rakyat dapat pentingnya peranan kelapa sawit, pemerintah telah merintis model pengembangan pembangunan perkebunan pentingnya peranan kelapa sawit, pemerintah telah merintis model pengembangan pembangunan perkebunan rakyat. Agar perkebunan rakyat dapat berkembang, maka peranan perkebunan besar sangat diperlukan untuk membantu dan membimbing perkebunan rakyat sebagai mitra dalam suatu sistem kerjasama yang saling menguntungkan dan berkesinambungan (Rachman dan Subroto, 1999).

Di Propinsi Bengkulu, sektor pertanian dan sub sektor perkebunan mempunyai andil dalam perekonomian daerah. Kontribusi sektor pertanian di Propinsi Bengkulu sebesar 30,69\% dan sub sektor perkebunan sebesar 5,95 \%. Perkebunan di Propinsi Bengkulu umumnya diusahakan oleh perkebunan besar negara, perkebunan besar swasta dan perkebunan rakyat (Suwarto, 2001).

Tabel 1. Luas Lahan dan Produksi Kelapa Sawit Perkebunan Rakyat di Propinsi Bengkulu Tahun 2004

\begin{tabular}{|c|c|c|c|c|c|}
\hline \multirow[b]{2}{*}{ Kabupaten } & \multicolumn{4}{|c|}{ Luas Lahan $(\mathrm{Ha})$} & \multirow{2}{*}{$\begin{array}{l}\text { Produksi } \\
\text { (Ton) }\end{array}$} \\
\hline & TBM & TM & TTM & Total & \\
\hline Bengkulu Utara & 9.937 & 10.173 & 59 & 20.169 & 183.037 \\
\hline Muko-Muko & 16.055 & 7.100 & 0 & 23.155 & 156.200 \\
\hline Seluma & 5.568 & 7.969 & 83 & 13.620 & 136.712 \\
\hline Bengkulu Selatan & 3.617 & 1.613 & 0 & 5.230 & 32.260 \\
\hline Kota Bengkulu & 599 & 1.261 & 0 & 1.860 & 29.003 \\
\hline Kaur & 1.686 & 381 & 0 & 2.067 & 6.858 \\
\hline Rejang Lebong & 5 & 15 & 0 & 20 & 270 \\
\hline Lebong & 7 & 6 & 0 & 13 & 105 \\
\hline Kepahiang & 10 & 5 & 0 & 15 & 88 \\
\hline \multicolumn{6}{|c|}{ Sumber : Dinas Perkebunan Propinsi Bengkulu, 2004} \\
\hline $\begin{array}{l}\text { Keterangan } \\
\text { TBM : Tanaman } \\
\text { TM : Tanaman } \\
\text { TTM : Tanaman }\end{array}$ & $\begin{array}{l}\text { enghasilk } \\
\text { ilkan } \\
\text { nghasilk }\end{array}$ & & & & \\
\hline
\end{tabular}

Dari Tabel 1 di atas, diketahui bahwa Kabupaten Bengkulu Utara merupakan salah satu daerah sentra produksi kelapa sawit di Propinsi Bengkulu. Tanaman kelapa sawit mempunyai peranan strategis dalam perekonomian Bengkulu, karena tanaman ini merupakan salah satu komoditas perkebunan andalan ekspor non migas, dan dalam proses produksi maupun 
pengolahannya mampu menciptakan kesempatan kerja yang dapat meningkatkan kesejahteraan masyarakat petani. Oleh karena itu, Pemerintah Daerah Bengkulu sangat berkepentingan dalam mengembangkan perkebunankelapasawit(Suwarto,2001)

Tabel 2. Kapasitas Pabrik Perusahaan Perkebunan Kelapa Sawit Besar Swasta Nasional di Kabupaten Bengkulu Utara

\begin{tabular}{clcc}
\hline \multirow{2}{*}{ No } & \multicolumn{2}{c}{ Nama Perusahaan } & \multicolumn{2}{c}{ Kapasitas Olah Pabrik (Ton/Jam) } \\
\cline { 3 - 4 } & & Terpasang & Terpakai / Aktual \\
\hline 1. & PT. Mitra Puding Mas / Alno Agro Utama & 65 & 30 \\
2. & PT. Agricinal & 60 & 45 \\
3. & PT. Bio Nusantara & & 45 \\
\hline
\end{tabular}

Sumber : Dinas Perkebunan Propinsi, 2004

Sejak berdiri, PT. Agricinal mempunyai komitmen untuk membina masyarakat sekitar dalam berkebun kelapa sawit. Pada tahap pertama PT. Agricinal memulai program pembinaan untuk masyarakat sekitar pada tahun 1988, dan efektif penanaman pada tahun 1989 dengan pembiayaan melalui fasilitas KUK (Kredit Usaha Kecil), dengan suku bunga komersil sebesar 17 \% pertahun. Program ini dinamakan Proyek Pembinaan Penduduk Berkebun Kelapa Sawit (P3BS). Pada dasarnya kerjasama antara petani mitra dengan PT. Agricinal sebagai pihak inti merupakan sistem kerjasama "Bapak Angkat". Untuk mengembangkan program tersebut, pada tahun 1997 pihak PT. Agricinal menerima permintaan gerakan koperasi untuk kerjasama membangun perkebunan kelapa sawit milik anggota koperasi. Koperasi tersebut adalah Koperasi Perkebunan Makmur Mandiri. Pada tahun 1998 PT. Agricinal membentuk Komite Pengembangan Kebun Anggota Koperasi/Plasma.

Hubungan kerjasama antara PT. Agricinal dengan petani sekitar disebut "kemitraan". "Kemitraan" selain menguntungkan bagi kedua belah pihak tetapi sekaligus akan memperbaiki struktur pembangunan perkebunan kelapa sawit rakyat di Kabupaten Bengkulu Utara. PT. Agricinal telah melakukan hubungan kerjasama dengan perkebunan rakyat di Kecamatan Putri Hijau, Ketahun, Napal Putih, Batiknau, Lais, Padang Jaya, Arga Makmur dan Giri Mulyo.

Perhitungan harga pokok produksi CPO berguna untuk mengetahui seberapa besar bahan baku (TBS) yang digunakan untuk menghasilkan CPO, berapa harga pokok total, harga pokok per unit ekuivalen dan alokasi biaya produksi selama satu periode. Perhitungan harga pokok produksi CPO dapat dijadikan dasar untuk menentukan harga jual CPO. Untuk mengetahui perkembangan harga CPO dimasa mendatang dilakukan peramalan 
Tujuan dari penelitian ini adalah untuk mengetahui jumlah pasokan TBS dari perkebunan rakyat Kabupaten Bengkulu Utara di PT. Agricinal (1), mengetahui hasil ramalan ketersediaan TBS di perkebunan rakyat Kabupaten Bengkulu Utara selama 16 bulan di masa mendatang (2), mengetahui hasil ramalan harga CPO di PT. Agricinal selama 16 bulan di masa mendatang (3) dan mengetahui harga pokok produksi CPO di PT Agricinal (4).

\section{METODOLOGI PENELITIAN}

Lokasi penelitian dipilih secara sengaja (purposive) di lima kecamatan Kabupaten Bengkulu Utara (Kecamatan Ketahun, Giri Mulyo, Putri Hijau, Batiknau dan Napal Putih) dan di PT Agricinal. Penelitian ini dilakukan pada bulan September-Okatober 2005. Metode analisis untuk pasokan TBS dari perkebunan rakyat Kabupaten Bengkulu Utara di PT. Agricinal digunakan analisis deskriptif. Dalam analisis deskriptif ini dijelaskan hubungan antara ketersediaan TBS di perkebunan rakyat Kabupaten Bengkulu Utara dengan jumlah pasokan TBS yang masuk ke PT. Agricinal disesuaikan dengan kapasitas pabrik.

Untuk mengetahui perkembangan ketersediaan TBS di perkebunan rakyat dan harga CPO di PT. Agricinal selama 16 bulan mendatang dilakukan peramalan jangka pendek dengan menggunakan metode pemulusan eksponensial. Metode ini mengalami dua kali pemulusan, sehingga dihasilkan ramalan yang akurat dan mendekati nilai aktual. Metode pemulusan eksponensial terbagi dua, pemulusan eksponensial tunggal dan pemulusan eksponensial ganda. (Lincolin, 2001)

1. Metode Pemulusan Eksponensial Tunggal

(Single Exponential Smoothing Method)

$$
A_{t}=\alpha Y_{t}+(1-\alpha) A_{t-1}
$$

\section{Metode Pemulusan Eksponensial Ganda (Double Exponential Smoothing Method)}

$$
A_{t}^{\prime}=\alpha A_{t}+(1-\alpha) A_{t-1}{ }^{\prime}
$$

Dengan dibantu oleh dua koefisien, yaitu

$$
a_{t}=2 A_{t}-A_{t}^{\prime} \text { dan } b_{t}=\frac{\alpha}{\left(A_{t}-A_{t}^{\prime}\right) 1-\alpha}
$$


Sehingga diperoleh persamaan ramalan :

$$
Y_{1+p}=a_{t}+b_{t} p
$$

\section{Dimana :}

$A_{t} \quad=$ Nilai pemulusan eksponensial tunggal pada periode $t$,

$A_{t}^{\prime} \quad=$ Nilai pemulusan eksponensial ganda pada periode $t$,

$\mathrm{Y}_{\mathrm{t}}=$ Nilai aktual $\mathrm{X}$ pada periode $\mathrm{t}$,

$\alpha=$ Konstanta pemulusan $(0<\alpha<1)$,

$a_{\mathrm{t}} \quad=$ Perbedaan antara nilai-nilai pemulusan eksponensial

$b_{\mathrm{t}} \quad=$ Slope suatu kurva

$Y_{1+p}=$ Hasil ramalan pada periode $t+p$

$\mathrm{p} \quad=$ Jumlah periode mendatang yang akan diramalkan

$\mathrm{t}=$ Periode ke- $\mathrm{t}$

Penentuan harga pokok produksi CPO di PT. Agricinal digunakan metode harga pokok masuk pertama keluar pertama (MPKP) dengan prinsip full costing.

Langkah-langkah perhitungan metode harga pokok MPKP dengan prinsip full costing (Harnanto 1991), sebagai berikut :

1. Identifikasi data kuantitas produksi

2. Perhitungan output dinyatakan dalam bentuk unit ekuivalen

3. Pengumpulan data total biaya produksi

4. Perhitungan harga pokok per unit ekuivalen

5. Alokasi total biaya produksi kepada produk selesai dan produk dalam proses akhir periode 


\section{HASIL DAN PEMBAHASAN}

\section{Analisis Pasokan TBS dari Perkebunan Rakyat Kabupaten Bengkulu Utara di PT. Agricinal}

Dalam melakukan "kemitraan", PT. Agricinal sebagai pihak inti menetapkan perjanjian dengan petani mitranya, isi perjanjian tersebut adalah sebagai berikut :

1. Petani peserta menyerahkan pengelolaan tanahnya kepadanya pihak inti untuk dibangun menjadi kebun kelapa sawit.

2. Petani peserta secara bersama-sama menyerahkan sertifikat/bukti kepemilikan tanah kepada bank pelaksana untuk digunakan sebagai agunan kredit.

3. Petani peserta bekerja sebagai tenaga kerja dan diwajibkan memelihara kebunnya sesuai dengan petunjuk pembinaan yang diberikan oleh petugas dari kebun inti.

4. Petani wajib menjual produksi TBS ke PT. Agricinal.

5. Petani wajib membayar angsuran kredit dan bunganya.

6. Perusahaan membantu mengusahakan Kredit Usaha Kecil (KUK).

7. Perusahaan membeli hasil kebun dengan harga yang layak di bawah pengawasan pemerintah yang berlaku.

8. Perusahaan memberikan pembinaan dan penyuluhan kepada petani.

9. Perusahaan menyerahkan kebun sesuai dengan standar fisik perkebunan kepada petani yang telah memenuhi persyaratan pada saat tanaman mencapai umur menghasilkan.

10. Perusahaan mengelola dana kredit.

Dalam isi perjanjian tersebut telah menjabarkan hak dan kewajiban masing-masing pihak. Kewajiban pihak inti dapat diartikan sebagai hak bagi pihak mitra dan sebaliknya. Perjanjian tersebut disampaikan oleh pihak inti secara lisan, sehingga petani mitra pada umumnya tidak atau kurang memahami isi perjanjian "kemitraan" tersebut, baik mengenai hak maupun kewajibannya sebagai petani mitra.

Walaupun PT. Agricinal telah melakukan hubungan kerjasama dengan petani perkebunan rakyat, akan tetapi sampai saat ini PT. Agricinal masih mengalami kekurangan bahan baku yang belum mampu memenuhi kapasitas terpasang pabrik. Kapasitas terpasang pabrik PT. Agricinal sebesar 65 ton TBS per jam dengan jumlah jam kerja selama 12 jam per hari. Jadi kapasitas terpasang pabrik selama satu hari adalah 780 ton TBS dan satu bulan penuh sebesar 23.400 ton TBS. Karena kapasitas terpasang pabrik tidak dapat terpenuhi, maka PT. Agricinal akhirnya 
menetapkan sendiri jumlah TBS minimal yang masuk untuk diproses atau sering disebut dengan kapasitas aktual. Kapasitas aktual PT. Agricinal, yaitu 45 ton TBS per jam, jadi kapasitas aktual selama satu hari adalah 540 ton TBS dan satu bulan penuh sebesar 16.200 ton TBS. Apabila jumlah TBS yang masuk ke pabrik belum mampu memenuhi kapasitas aktualnya, maka TBS tersebut akan disimpan terlebih dahulu. Perusahaan yang terus-menerus mengolah TBS dalam jumlah sedikit akan menyebabkan terjadinya kelebihan biaya produksi, sehingga pada akhirnya perusahaan akan mengalami kerugian. Biasanya TBS disimpan selama satu sampai dua hari, TBS yang disimpan terlalu lama akan mengakibatkan tingkat ALB-nya (Asam Lemak Bebas) semakin tinggi sehingga kualitas minyak CPO akan rendah dan harga jual CPO menurun.

Berdasarkan hasil penelitian, diketahui rata-rata jumlah TBS yang masuk ke PT. Agricinal berjumlah 13.308,87 ton, berasal dari perkebunan rakyat di Kabupaten Bengkulu Utara sebesar $6.734,69$ ton atau $50,60 \%$ dan $6.574,18$ ton atau $49,40 \%$ berasal dari perkebunan inti perusahaan Berdasarkan kapasitas aktual pabrik, PT. Agricinal masih mengalami kekurangan bahan baku sebesar 2.892 ton atau $17,85 \%$ per bulannya.

Terjadinya kekurangan bahan baku tersebut dipengaruhi oleh :

1. Tanaman kelapa sawit merupakan komoditi perkebunan relatif baru di Propinsi Bengkulu, sehingga masih banyak petani belum mengetahui mengenai tatacara pemeliharaan pembudidayaan tanaman kelapa sawit dengan baik.

2. Musim, pada bulan tertentu produksi kelapa sawit akan mengalami kenaikan dan pada bulan lainnya produksi kelapa sawit mengalami penurunan

3. Umur tanaman kelapa sawit. Hasil produksi kelapa sawit sangat dipengaruhi oleh umur tanamannya. Umur produktif tanaman kelapa sawit umumnya antara 5 sampai 15 tahun

4. Kurangnya sarana angkutan TBS dari perkebunan rakyat

Untuk mengatasi permasalahan tersebut, PT. Agricinal telah melakukan perluasan areal lahan perkebunan inti dan memperluas "kemitraan". Melalui pola "kemitraan" PT. Agricinal memberikan pinjaman modal investasi untuk biaya pembangunan kebun hingga kebun tersebut menghasilkan. Biaya investasi tersebut menjadi hutang bagi petani yang pembayarannya diangsur dengan hasil penjualan TBS-nya kepada PT. Agricinal. Cicilan pembayaran angsuran tersebut sebesar $15 \%$ dari setiap kali panen. 
Penarikan petani swadaya menjadi petani mitra diutamakan kepada petani yang mempunyai lahan dan tenaga kerja untuk membangun kebun, yang letaknya dekat dengan pabrik PT. Agricinal. Dengan demikian pihak PT. Agricinal akan lebih mudah dalam melakukan pembinaan dan pengarahan serta dapat mengontrol kegiatan petani mitranya.

Tabel 3. Data Ketersediaan TBS di Perkebunan Rakyat Kabupaten Bengkulu Utara

\begin{tabular}{|c|c|c|c|c|}
\hline \multicolumn{5}{|c|}{ Ketersediaan TBS di Perkebunan Rakyat Kabupaten Bengkulu Utara (Ton) } \\
\hline \multicolumn{3}{|c|}{ Masuk ke PT. Agricinal } & \multirow{2}{*}{$\begin{array}{c}\text { Belum/tidak Masuk ke } \\
\text { PT. Agricinal }\end{array}$} & \multirow{2}{*}{ Total } \\
\hline Plasma/Mitra & Swadaya & Total & & \\
\hline $\begin{array}{l}5.075,69 \\
(44,66 \%)\end{array}$ & $\begin{array}{l}1.659,00 \\
(14,60 \%)\end{array}$ & $\begin{array}{l}6.734,69 \\
(59,26 \%)\end{array}$ & $\begin{array}{l}4.630,18 \\
(40,74 \%)\end{array}$ & $\begin{array}{c}11.364,87 \\
(100 \%)\end{array}$ \\
\hline
\end{tabular}

Untuk melihat pola perkembangan ketersediaan TBS di perkebunan rakyat Kabupaten Bengkulu Utara. Dengan menggunakan data bulanan selama 32 bulan terakhir (bulan Januari 2003 Agustus 2005), dilakukan perhitungan indeks musim bulanan dengan menggunakan metode analisis perbandingan terhadap rata-rata bergerak (ratio to moving average).

Komponen musiman runtun waktu diukur dalam bentuk nilai indeks. Interprestasi nilai indeks mencerminkan besarnya pengaruh musiman untuk suatu segmen tahun tertentu. Berkaitan dengan perbandingan nilai terhitung atau nilai yang diharapkan dari segmen tersebut (bulanan) dengan ratarata keseluruhan untuk semua segmen sepanjang tahun. Dengan demikian nilai indeks bulanan menunjukkan kenaikan dan penurunan yang diharapkan dalam tingkat aktivitas bulanan.

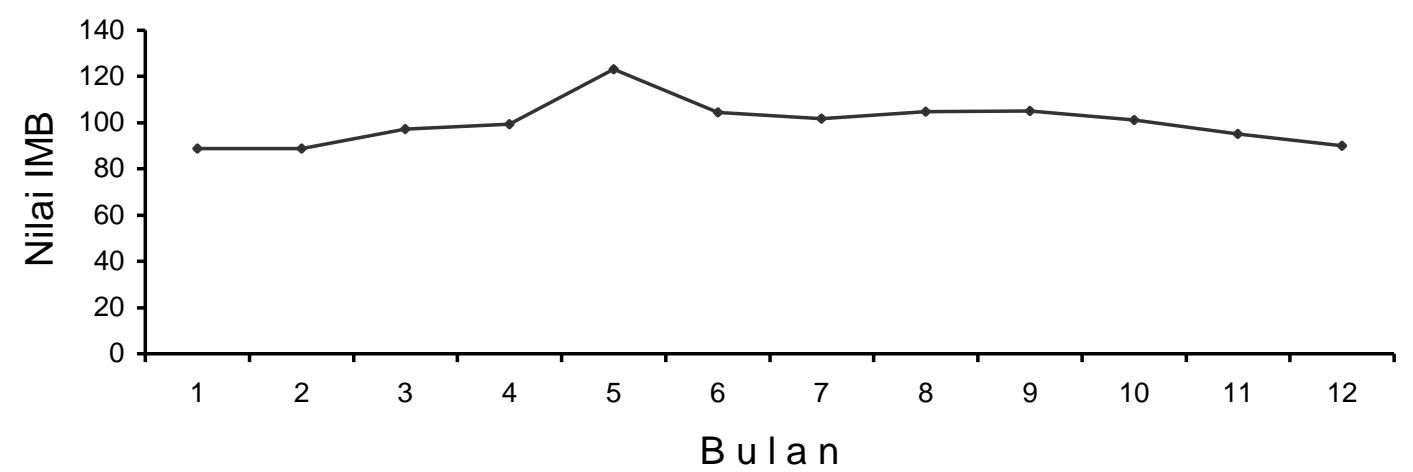

Gambar 1. Grafik Nilai Indeks Musim Bulanan Ketersediaan TBS di Perkebunan Rakyat Kabupaten Bengkulu Utara mulai dari Bulan Januari 2003 sampai Agustus 2005 
Untuk mengetahui jumlah ketersediaan TBS di perkebunan rakyat Kabupaten Bengkulu Utara selama 16 bulan mendatang, dilakukan peramalan jangka pendek dengan menggunakan metode pemulusan eksponensial ganda (double exponential smoothing).

Untuk peramalan ketersediaan TBS di perkebunan rakyat Kabupaten Bengkulu Utara digunakan $\alpha=0,50$ karena menghasilkan nilai MSE terkecil dan diperoleh persamaan : $\mathrm{Yt}_{(1+p)}=$ $16.438,92+407,93$ (p). Dari hasil persamaan tersebut dilakukan peramalan selama 16 bulan mendatang, yaitu mulai dari bulan September 2005 sampai Desember 2006.

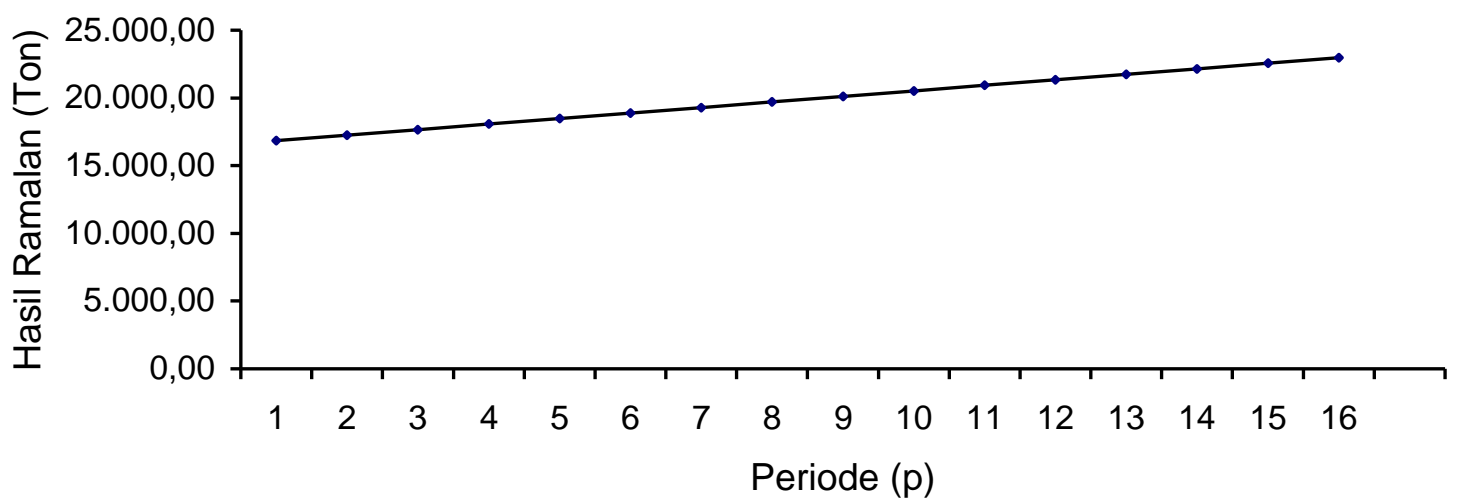

Gambar 2. Grafik Hasil Ramalan Ketersediaan TBS di Perkebunan Rakyat Kabupaten Bengkulu Utara mulai dari Bulan September 2005 sampai Desember 2006

Dari Gambar 2, diketahui bahwa hasil ramalan ketersediaan TBS di perkebunan rakyat Kabupaten Bengkulu Utara selama 16 bulan mendatang mengalami peningkatan. Peningkatan hasil produksi TBS tersebut dikarenakan kondisi geografis Kabupaten Bengkulu Utara memiliki topografi datar atau sedikit bergelombang serta didukung curah hujan yang cukup baik dan merata disepanjang tahun, yang sangat cocok untuk dikembangkan sebagai daerah perkebunan kelapa sawit. Selain itu, adanya ketersediaan pabrik pengolahan kelapa sawit, salah satunya PT. Agricinal yang mampu menampung TBS, sehingga petani mempunyai pasar yang pasti untuk memasarkan hasil produksinya. Dalam hal ini peranan perkebunan besar swasta dan pemerintah daerah sangat dibutuhkan untuk memberikan pembinaan dan pengarahan kepada petani, karena mengingat tanaman kelapa sawit merupakan salah satu komoditi perkebunan yang relatif baru di Propinsi Bengkulu.

Dari hasil ramalan ketersedian TBS di perkebunan rakyat Kabupaten Bengkulu Utara selama 16 bulan di masa mendatang, PT. Agricinal dapat menyusun perencanaan kebijaksanaan agar 
perusahaan tidak mengalami kekurangan bahan baku di masa mendatang, misalnya mempererat dan memperluas hubungan kerjasamanya dengan petani perkebunan kelapa sawit rakyat di Kabupaten Bengkulu Utara, melalui pola "kemitraan" yang saling menguntungkan dan berkesinambungan.

\section{Peramalan Harga CPO di PT. Agricinal}

Sebelum melakukan peramalan, untuk melihat pola perkembangan harga CPO di PT. Agricinal dilakukan perhitungan indeks musim bulanan terhadap data deret waktu selama 56 bulan, yaitu mulai dari bulan Januari 2002 sampai bulan Agustus 2005. Dalam pengolahan data ini digunakan metode analisis perbandingan terhadap rata-rata bergerak (ratio to moving average)

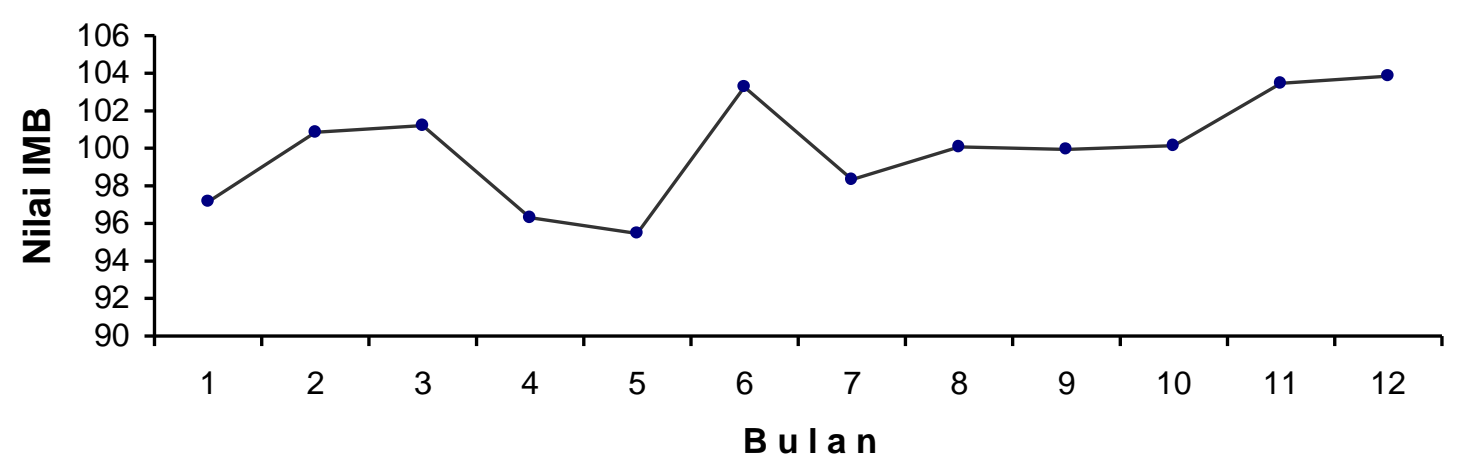

Gambar 3. Grafik Indeks Musim Bulanan Harga CPO mulai dari Bulan Januari 2002 sampai Agustus 2005

Berdasarkan informasi dan pengamatan selama penelitian, terjadinya fluktuasi harga CPO ini disebabkan oleh :

1. Pengaruh perputaran musim pada negara tujuan ekspor CPO Indonesia (negara-negara MEE, Jepang, Cina, Singapura dan lainnya)

2. Untuk CPO lokal lelang bukan untuk mencari harga tertinggi tetapi untuk menunjang harga minyak goreng

3. Harga CPO dipengaruhi oleh adat istiadat atau kebiasaan, misalnya lebaran dan natal.

Untuk mengetahui harga CPO di PT. Agricinal di masa mendatang dilakukan peramalan dengan menggunakan metode pemulusan eksponensial ganda (double exponential smoothing).

Peramalan harga CPO di PT. Agricinal digunakan $\alpha=0,50$ karena menghasilkan nilai MSE terkecil dan diperoleh persamaan : $\mathrm{Yt}_{(1+\mathrm{p})}=3.864,33+86,27(\mathrm{p})$. Dari hasil persamaan tersebut 
dilakukan peramalan harga CPO di PT. Agricinal selama 16 bulan mendatang, yaitu mulai dari bulan September 2005 sampai Desember 2006

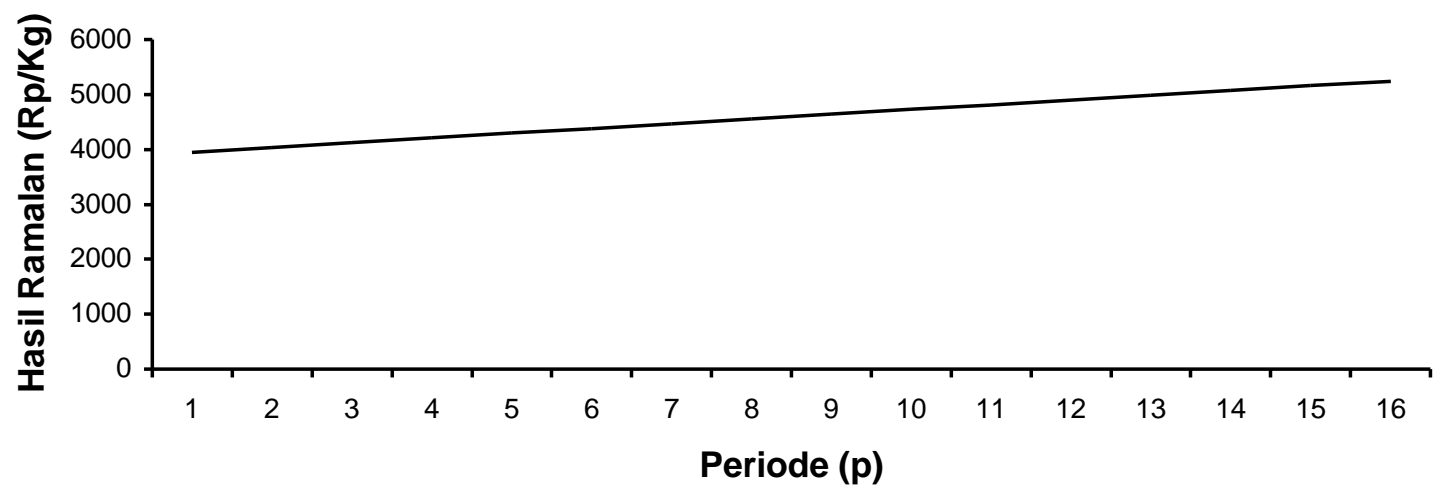

Gambar 4. Grafik Hasil Ramalan Harga CPO mulai dari Bulan September 2005 sampai Desember 2006

Berdasarkan Gambar 4, diketahui bahwa peramalan harga CPO di PT. Agricinal untuk 16 bulan mendatang menunjukkan kecenderungan meningkat. Peningkatan harga CPO ini disebabkan karena jumlah permintaan akan kebutuhan CPO dari waktu ke waktu selalu meningkat terutama pada saat menjelang perayaan hari besar, misalnya perayaan hari raya idul fitri, natal, idul adha dan lain sebagainya.

\section{Penentuan Harga Pokok Produksi CPO di PT. Agricinal}

Penentuan harga pokok produksi CPO di PT. Agricinal menggunakan metode harga pokok MPKP dengan prinsip full costing, yaitu elemen biaya produksi yang diperhitungkan adalah biaya Gambar 4. Grafik Hasil Ramalan Harga CPO mulai dari Bulan September 2005 sampai Desember 2006

Berdasarkan Gambar 4, diketahui bahwa peramalan harga CPO di PT. Agricinal untuk 16 bulan mendatang menunjukkan kecenderungan meningkat. Peningkatan harga CPO ini disebabkan karena jumlah permintaan akan kebutuhan CPO dari waktu ke waktu selalu meningkat terutama pada saat menjelang perayaan hari besar, misalnya perayaan hari raya idul fitri, natal, idul adha dan lain sebagainya. Produksi variabel dan biaya produksi tetap. Penentuan harga pokok produksi CPO terdiri dari biaya bahan baku dan biaya konversi (biaya tenaga kerja dan biaya overhead pabrik). 
Tabel 4. Data Penjualan dan Biaya CPO di PT. Agricinal pada Akhir Periode Bulan Agustus 2005

\begin{tabular}{|c|c|c|}
\hline No & Keterangan & Jumlah \\
\hline 1 & $\begin{array}{l}\text { Hasil Penjualan (Rp) } \\
3.603 .512 \mathrm{Kg} \times \mathrm{Rp} 3.860,00 / \mathrm{Kg}\end{array}$ & 13.909 .556 .320 \\
\hline 2 & $\begin{array}{l}\text { Data Produksi (Ton) } \\
\text { a. Jumlah bahan baku selesai diproses } \\
\text { b. Jumlah bahan baku dalam proses } \\
(100 \% \text { BB, } 75 \% \text { BK) }\end{array}$ & $\begin{array}{c}17.424,26 \\
7,24\end{array}$ \\
\hline 3 & $\begin{array}{l}\text { Biaya Produksi (Rp) } \\
\text { a. Biaya bahan baku (BB) } \\
\text { - Biaya bahan baku awal } \quad 3,93 \text { Ton } \\
\text { - Biaya bahan baku masuk 17.427,57 Ton } \\
\text { Total biaya bahan baku (BB) } \\
\text { b. Biaya konversi (BK) } \\
\text { - Biaya tenaga kerja } \\
\text { 1. biaya tenaga kerja variabel } \\
\text { 2. biaya tenaga kerja tetap } \\
\text { Total Biaya tenaga kerja } \\
\text { - Biaya overhead pabrik } \\
\text { 1. BOP variabel } \\
\text { i. biaya pengolahan } \\
\text { ii. biaya pemeliharaan pabrik } \\
\text { iii. biaya umum dan administrasi } \\
\text { 2. BOP tetap } \\
\text { i. biaya penyusutan } \\
\text { ii. pajak tanah (PBB) dan iuran HGU } \\
\text { iii. biaya asuransi pabrik } \\
\text { Total Biaya BOP } \\
\text { Total Biaya Produksi }\end{array}$ & $\begin{array}{r}204.775 .710 \\
408.490 .693 \\
861.062 .448 \\
\\
553.844 .456 \\
58.934 .631 \\
3.962 .075 \\
2.091 .070 .013 \\
11.641 .794 .006\end{array}$ \\
\hline 4 & $\begin{array}{l}\text { Biaya Non Produksi } \\
\text { a. Biaya Umum dan Administrasi } \\
\text { b. Biaya Penjualan } \\
\text { Total Biaya Non Produksi }\end{array}$ & $\begin{array}{r}167.718 .472 \\
12.294 .814 \\
180.013 .286\end{array}$ \\
\hline
\end{tabular}

Sumber : PT. Agricinal, Agustus 2005

Susunan laporan perhitungan harga pokok produksi CPO di PT. Agricinal pada akhir periode bulan Agustus 2005 adalah sebagai berikut : 
Tabel 5. Perhitungan Harga Pokok Produksi CPO Akhir Periode Bulan Agustus 2005 per unit ekuivalen

\begin{tabular}{cccc}
\hline $\begin{array}{c}\text { Keterangan biaya } \\
\text { Produksi }\end{array}$ & $\begin{array}{c}\text { Unit Ekuivalen } \\
\text { (Ton) }\end{array}$ & $\begin{array}{c}\text { Jumlah biaya } \\
(\mathrm{Rp})\end{array}$ & $\begin{array}{c}\text { Biaya/unit ekuivalen } \\
\text { (Rp/Ton) }\end{array}$ \\
\hline Biaya bahan baku & $17.431,50^{*}$ & $9.017 .395 .570,00$ & $517.304,62$ \\
Biaya tenaga kerja & $17.429,69^{* *}$ & $533.328 .423,00$ & $30.598,85$ \\
Biaya overhead pabrik & $17.429,69^{* *}$ & $2.091 .070 .013,00$ & $119.971,73$ \\
$\quad$ Total & $52.290,88$ & $11.641 .794 .006,00$ & $667.875,20$ \\
\hline
\end{tabular}

Keterangan unit ekuivalen :

* Bahan baku $\quad=17.424,26(100 \%)+7,24(100 \%)$

$=17.431,50$ Ton

${ }^{* *}$ Konversi $\quad=17.424,26(100 \%)+7,24(75 \%)$

$=17.429,69$ Ton

Berdasarkan analisis Tabel 9, dilakukan perhitungan harga pokok produksi CPO selesai diproses $\left(\mathrm{HPP}_{\mathrm{FG}}\right.$ ) dan harga pokok produksi $\mathrm{CPO}$ belum selesai diproses (HPP ${ }_{\text {WIP }}$ ) pada PT. Agricinal akhir periode bulan Agustus 2005 adalah :

$\mathrm{HPP}_{\mathrm{FG}}=$ Jumlah TBS selesai diproses $\mathrm{x}$ Biaya per unit ekuivalen

$=17.424,26$ Ton $\times$ Rp $667.875,20 /$ Ton

$=\operatorname{Rp} 11.637 .231 .132,35$

$H P P_{\text {WIP }}=$ Total biaya produksi $-\mathrm{HPP}_{\mathrm{FG}}$

$=\operatorname{Rp} 11.641 .794 .006,00-\operatorname{Rp} 11.637 .231 .132,35$

$=\operatorname{Rp} 4.562 .873,65$

Dari perhitungan harga pokok produksi CPO, maka laba bersih yang diterima PT. Agricinal pada akhir periode bulan Agustus 2005, yaitu:

Tabel 6. Perhitungan Laba Bersih PT. Agricinal pada Akhir Periode Bulan Agustus 2005

\begin{tabular}{lc}
\hline \multicolumn{1}{c}{ Keterangan } & Jumlah (Rp) \\
\hline Hasil Penjualan CPO & $13.909 .556 .320,00$ \\
Harga Pokok Produksi CPO (Biaya Produksi) & $(11.641 .794 .006,00)$ \\
Laba Kotor & $2.267 .762 .314,00$ \\
Biaya Non Produksi & \\
Laba Bersih & $(180.013 .286,00)$ \\
\hline
\end{tabular}


ISSN 1412 - 8837

\section{KESIMPULAN DAN SARAN}

\section{Kesimpulan}

Berdasarkan hasil dan pembahasan penelitian dapat disimpulkan sebagai berikut :

1. Pasokan bahan baku dari perkebunan rakyat Kabupaten Bengkulu Utara di PT. Agricinal ratarata per bulannya sebesar $6.734,69$ ton TBS atau $50,60 \%$ dari jumlah TBS yang masuk ke PT. Agricinal.

2. Hasil ramalan ketersediaan TBS di perkebunan rakyat Kabupaten Bengkulu Utara untuk 16 periode (bulan) mendatang memiliki kecenderungan meningkat. Peningkatan TBS ini terjadi karena berdasarkan kondisi Geografis Kabupaten Bengkulu Utara sangat cocok untuk budidaya perkebunan kelapa sawit dan adanya pabrik pengolahan CPO, salah satunya yaitu PT. Agricinal yang mampu menampung TBS, sehingga petani mempunyai pasar yang pasti untuk menjual hasil produksinya.

3. Hasil ramalan harga CPO yang diterima PT. Agricinal untuk 16 periode (bulan) mendatang memiliki kecenderungan meningkat, hal ini disebabkan semakin meningkatnya permintaan CPO karena kebutuhan CPO sebagai bahan baku minyak goreng, margarin, sabun dan produk kosmetik semakin meningkat.

4. Dari hasil perhitungan harga pokok produksi CPO di PT. Agricinal akhir periode bulan Agustus 2005, diketahui bahwa harga pokok CPO selesai diproses adalah sebesar Rp 11.637.231.132,35 dan harga pokok CPO belum selesai diproses sebesar Rp 4.562.873,65

\section{Saran}

Berdasarkan hasil dan pembahasan penelitian ada beberapa saran yang dapat dikemukakan, yaitu sebagai berikut :

1. Untuk mengatasi permasalahan kekurangan bahan baku, PT. Agricinal harus melakukan perluasan areal lahan perkebuinan inti dan meningkatkan harga TBS yang pada akhirnya dapat memperluas hubungan kerjasama dengan petani melalui pola "Kemitraan".

2. Dalam pola "kemitraan" PT. Agricinal seharusnya lebih transparan dalam menetapkan isi perjanjian serta mempertimbangkan aspirasi dan kepentingan petani, sehingga diharapkan pola "kemitraan" tersebut benar-benar dipahami oleh petani dan dapat memberikan keuntungan bagi kedua belah pihak. 
3. Hasil ramalan dan penentuan harga pokok produksi CPO di PT. Agricinal dapat dijadikan acuan dalam melakukan perencanaan kebijaksanaan di masa mendatang. Perlu disadari peramalan tetaplah peramalan, sehingga dalam perencanaan kebijaksanaan perusahaan tersebut perlu dimasukkan dan dipertimbangkan beberapa informasi lain seperti faktor musim, adat istiadat dan lain sebagainya.

\section{DAFTAR PUSTAKA}

Arsyad, Lincolin. 2001. Peramalan Bisnis. BPFE UGM. Yogyakarta.

Harnanto. 1991. Akuntansi Biaya. Fakultas Ekonomi. UGM. Yogyakarta

Rachman. A dan Subroto. B. 1999. Kebijaksanaan dan Strategi Pengembangan Agrobisnis Kelapa Sawit di Indonesia. Jurnal Agro Ekonomika. No. 1-29.

Suwarto. 2001. Peluang, Kendala dan Langkah-Langkah yang Perlu Diambil Untuk Pengembangan Kelapa Sawit Rakyat di Propinsi Bengkulu. Jurnal Perkebunan Kelapa Sawit. Dinas Perkebunan Propinsi Bengkulu. Bengkulu 